\title{
Global Trends And Debt Relief For Asia, Latin America, And Africa: A Multiple Discriminant Analysis
}

Farhad F.Ghannadian, (E-mail: ghannadian_f@ mercer.edu), Mercer University John R. Miller, (E-mail: Miller_jr@mercer.edu), Mercer University

\begin{abstract}
Emerging country debt levels are at an all time high. There seems to be a great need to find a solution to the mounting level of external debt in the continents of Asia, South America and Africa. Utilizing multiple discriminant analysis this study looks at whether indebted countries in the various continents responded differently to macroeconomic factors and whether the level of debt made those economies respond to macroeconomic measures. This study supports the notion that Asian countries are more affected by debt factors influencing their economies than countries in Latin America or Africa. The study further shows that various debt levels; e.g.; high, medium, versus low have a significant influence on macroeconomic factors. Therefore this article strongly supports policies for country debt reduction worldwide.
\end{abstract}

\section{INTRODUCTION}

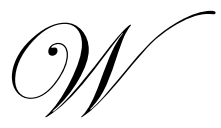

these funds.

hile evidence suggests a growing trend in World debt patterns, countries in different categories have benefited (suffered) differently. The purpose of this study is to understand these patterns and behaviors which may have a policy implication in countries involved in lending and receiving

By the 1970's sixty countries were classified as low income countries by the World Bank. These countries had a total debt of approximately $\$ 25$ billion. This amount had increased by twenty fold to over 523 billion by 2002. For African countries, where a major bulk of this type of debt occurs, this amount had grown by almost thirty fold in the same time period (1970-2002). The three largest countries on the debt scale in the 1990's were Brazil with a debt of $\$ 116$ billion, Mexico with over $\$ 90$ billion, and Argentina with a $\$ 60$ billion debt. About a third of these debts were owed to the IMF and the World Bank. In the same three decades about $\$ 550$ billion was paid in principal and interest on these loans. These loans are worth less than this amount and an equivalent amount is still owed to the creditors.

Some of the highly indebted countries (HICs) made the situation worse by mismanagement of the funds and many of the loans given to these countries escaped the country in the form of theft or capital flight. In general, sufficient funds were not invested in projects yielding enough to service the debt. Some countries such as South Korea with a high debt level stunned the world with their push for an export oriented economy. With their GDP growth rates in excess of 10\%, the South Koreans were able to service and reduce their debt levels in the late 1980's.

Solutions to remedy the debt problem have included forgiveness of the debt, debt restructuring, repurchasing of the debt using market forces, the use of taxpayer resources to sponsor a settlement and other mixed proposals. The most famous of these plans became known as the Brady plan named after U.S. Secretary of Treasury Nicholas Brady where the governments of creditor countries such as the U.S. and Europe would conduct large scale debt reduction plans with the private banks hence subsidizing most of these loans. In exchange the government of these countries would engage in sound economic policies to further the growth of the country and its stability. Some 
of these policies were successful and some were unsuccessful. The descriptions of these events are beyond the scope of this paper.

\section{RECENT EVENTS ON LDC DEBT}

As recently as June of 2006 the G- 8 ministers were concerned that the big emerging lenders; South Korea, China, India and Brazil were extending too much debt through their official export credit services to countries that could ill afford to have this form of debt. The issue was that an unsustainable debt would recreate the lend and forgive cycle which previously existed. (WSJ, 6-12-06). One of the countries particularly aggressive in its lending had been China. China had provided over $\$ 10$ billion of loans and export credits to the nations of sub-Saharan Africa to improve their infrastructure. Beijing has given over $\$ 800$ million to Sudan and is also financing dam projects in Ghana and Mozambique.

A recent World Bank Study also has shown that countries which had worked hard in reducing their loans such as Uganda, Ethiopia, Bolivia, and Nicaragua are again in trouble because of excess borrowing beyond their ability to repay.

The IMF has a new program known as the "Heavily Indebted Poor Country Initiative (HIPC)" Under this initiative countries will be able to write off some portion of their debt to various countries. The theory behind this initiative to reduce debt was based on the fact that economic growth in these countries was prevented due to the high debt burden. As recently as October of 2006 the Kyrgyz Republic's \$ 2 billion U.S. external debt was reduced to half. This was done under obligation by the government to make certain reforms given their political climate. (Country Monitor, 10-16-06). The amount targeted for debt relief is approximately $\$ 17$ billion. In addition there is also a "Multilateral Debt Relief Initiative (MDRI) that began in July of 2006 to provide $\$ 37$ billion in debt relief over the next 40 years. Many of these debts are for better health services, cleaner water, and poverty and education relief. Only countries which have graduated from the HIPC initiative will be eligible for the MDR initiative. According to the World Bank, nineteen countries will receive a 100\% cancellation of their eligible debt. These countries include Bolivia, Honduras, Mozambique, Nicaragua, Niger, Ghana, Senegal and Zambia.

In 2004, the IMF conducted an empirical study which assessed the effects of external debt on growth in low-income countries with a focus on the indirect effects of debt on public investment (Clements et.al. 2004). This study found that high levels of debt can depress economic growth only after the face value of the debt reaches about $50 \%$ of GDP, or its net present value hits $20-25 \%$ of GDP. In other words reduction of debt in low income countries could add 0.8-1.1 percent to their per capita GDP growth rates. Also the cost of servicing the public debt does depress public investment. The finding was that for every one percent increase in debt service, public investment as a percent of GDP is reduced by 0.2 percent.

The strong implications of this study directly link the effect of debt to other economic factors. It is important for a study to look at the impact of debt based on geographical factors i.e. continent or region versus economic growth factors and to see if the level of debt makes a difference in the sensitivity of macroeconomic factors. The study detailed below uses a discriminant model to analyze these two factors.

\section{EMPIRICAL ANALYSIS:}

\section{Methodology}

The use of any discriminant analysis model is essentially an adaptation of a regression analysis. In discriminant analysis, the input data matrix is created using several quantitative variables with the objects further grouped. In our study we have a group of industries and within the group we have some corporations who are more internationally diversified than others. The effectiveness of discriminant analysis rests on the existence of predictor variables that are different from the mean value from one criterion group to another. The analysis makes two assumptions: One is that the correlations between two predictor variables are the same in the respective populations; and two, the variances of the predictor variables are the same in the respective populations. 
Therefore the discriminant function uses a weighted combination of predictor variables to classify objects into one of the criterion variable groups. DV is the nomenclature the discriminant variable defined as the weighted sum of values on individual predictor variables. Each object will have a discriminant object score that will entirely depend upon its values on the various predictor variables. Therefore the discriminant function is written as:

$\mathrm{DV}=\beta 1 \times 1+\beta 2 \times 2 \quad \ldots \ldots . \beta \mathrm{i}$ xi

Where DV is the discriminant score, $x 1, x 2 \ldots . . x i$ are the predictor variables. $\beta 1, \beta 2$ and $\beta i$ are the weights associated with each of the respective predictor variables.

\section{Features Of Multiple Discriminant Analysis}

Multiple discriminant analysis is different from regression in that most of the group's observations cluster around the group's centroids. To determine which group an observation belongs to one can visually graph them and measure the distance to each of the centroids. Logically one can assign observations to the group represented by the closest centroids. Euclidean distance between two points (A1, B1) and (A2, B2) in two dimensions can be measured by:

Distance $=\left[(\mathrm{A} 1-\mathrm{A} 2)^{2}+(\mathrm{B} 1-\mathrm{B} 2)^{2}\right]^{1 / 2}$

Equation 2 can be generalized to any number of dimensions; however, equation 2 fails to account for the differences in variances of independent variables. If one were to allow for differences in variances of the independent variables and distances from observation $i$ to the centroid $j$, then the distance Dij can be defined the distance as:

$\operatorname{Dij}=\sqrt{ } \sum(X j k-\ddot{X j k})^{2} / s^{2} j k$

To further to account for differences in covariances of the independent variables, the Mahalanobis distance measure can be used to refine equation number 3. (Ragsdale, 2001) This approach is the best approach when there are more than two groups to classify and the relationship of the dependent variable and independent variable is not linear. The Mahalanobis distance measure is the technique employed in the study described below

\section{Sample Size}

Based on the availability of the data, a sample of 10 countries was chosen from the continents of Asia, Africa, and Latin America. All these countries have significant debt and are responding differently to their external debt factors. Table one illustrates the countries in the Sample.

Two sets of studies were conducted. One, the idea of which group of countries are more deserving of debt relief was investigated. The hypothesis that either a country in Africa would need to limit its debt more than others or whether the Asian countries were more successful in receiving and utilizing debt was investigated.

A second hypothesis was investigated to see if the level of debt would make any difference in the way the macroeconomic variables would respond to them. The thirty countries were classified as having High Debt, Medium Debt or Low Debt.

\section{Discriminant Analysis Based On Geographical Location}

A multiple discriminant analysis was performed using the 3 categories as the dependent variable. The independent variables were determined using debt plus one of the other (A, B, C, D, or E) variables. Software was used that determines the centroiods for each of the three groups. Each item is predicted to fall in one of the three categories based on the smallest distance from the centroid using the Mahalonobis distance measure. 
The countries' external debt level can have a substantial impact on the countries trade and the current account and on its overall economic growth. The macroeconomic variables which were used here were as follows: These variables were the A- Current Account in U.S. dollars, B- The current account as a percent of GDP, C- the GDP measured in country's currency, D- Percent of GDP growth, E- GDP in U.S.dollars. These measures are useful in illustrating the growth factors of the economy domestically as opposed to international trade factors.

\section{EXHIBIT 1}

\section{Countries Of Study}

\begin{tabular}{|c|c|c|}
\hline Group 1 (Asia) & Group 2 (Africa) & Group 3 (Latin America) \\
\hline India & Botswana & Chile \\
\hline Indonesia & Burundi & El Salvador \\
\hline Israel & Cameroon & Guatemala \\
\hline Jordan & Congo & Mexico \\
\hline Malaysia & Ethiopia & Panama \\
\hline Mongolia & Kenya & Barbados \\
\hline Nepal & Morocco & Uruguay \\
\hline Pakistan & Nigeria & Peru \\
\hline Sri Lanka & Uganda & Paraguay \\
\hline Bangladesh & Chad & \\
\hline
\end{tabular}

In Exhibit 2 a discriminant function analysis was used for determining which variables discriminate between two or more naturally occurring groups. This allowed the study to determine the best predictors of the impact of debt on macroeconomic variables. In multiple discriminant analysis, as in this study, a discriminant factor distinguishing between the three groups was made.

\section{EXHIBIT 2}

Individual Indicator coefficient discriminate function based on Geography

\begin{tabular}{|c|c|c|c|c|c|}
\hline $\begin{array}{c}\text { Classification } \\
\text { Matrix }\end{array}$ & $\begin{array}{c}\text { Current Account } \\
\text { in U.S. Dollars } \\
\text { Correct \% }\end{array}$ & $\begin{array}{c}\text { Current Account } \\
\text { as percent of } \\
\text { GDP Correct \% }\end{array}$ & $\begin{array}{c}\text { The GDP } \\
\text { measured in } \\
\text { Country's } \\
\text { currency } \\
\text { Correct \% }\end{array}$ & $\begin{array}{c}\text { Percent of GDP } \\
\text { Growth Correct } \\
\%\end{array}$ & $\begin{array}{c}\text { GDP in U.S. } \\
\text { Dollars Correct } \\
\%\end{array}$ \\
\hline $\begin{array}{c}\text { Group1: Asian } \\
\text { Countries }\end{array}$ & $92.50^{*}$ & $67.50^{*}$ & $100.00^{*}$ & $66.25^{*}$ & $96.875^{*}$ \\
\hline $\begin{array}{c}\text { Group 2: } \\
\text { African Countries }\end{array}$ & 16.25 & 31.25 & 10.00 & 42.50 & 40.625 \\
\hline $\begin{array}{c}\text { Group 3: Latin } \\
\text { American } \\
\text { Countries }\end{array}$ & 29.375 & 31.25 & 37.50 & 27.50 & 32.50 \\
\hline Overall \% Correct & 46.04 & 43.33 & 49.17 & & 56.42 \\
\hline
\end{tabular}

* Indicates items $\geq 50 \%$ correct

An analysis of Exhibit 2 reveals that the Asian countries were correctly classified with respect to macroeconomic factors such as current account, GDP, and GDP growth rates. The asterisk shows that the classification is significant. However, the other countries of Africa and Latin America were not correctly classified. This could mean that reduction of debt or changes in the debt level could significantly affect the overall health of these Asian countries. It also indicates that the Latin American countries and African countries may not be able to affect these economic factors by changing their debt structure. It is possible that since the economies of those two 
continents; Africa and South America are lesser developed, the debt factor has lesser impact on their economies. Another possibility is that the economies of the Asian countries are integrated further in trade and investment within the continent and differential debt policies should be directed towards them. When one views the overall classification of all, the only robust classification is GDP in U.S. dollars indicating that the debt factor has significance with respect to the standing of the country with respect to international financial position of the country.

\section{Discriminant Analysis Based On Level Of Debt}

The thirty countries in our sample were divided in to three groups: High Level Debt, Medium Level Debt, and Low Debt. The Group was hence divided as follows in Exhibit 3 As one can see; there is a mix of countries from the three continents in all the groups.

\section{EXHIBIT 3}

Classification of Debt Levels

\begin{tabular}{|c|c|c|}
\hline High Level Debt Countries & Medium Debt Level Countries & Low Level Debt Countries \\
\hline Mexico & Indonesia & Sri Lanka \\
\hline Panama & Uruguay & Pakistan \\
\hline Chile & Jordan & Bangladesh \\
\hline India & Kenya & Uganda \\
\hline Botswana & Cameroon & Ethiopia \\
\hline Nigeria & Congo & Burundi \\
\hline Israel & Barbados & Chad \\
\hline Malaysia & Guatemala & Nepal \\
\hline Peru & Paraguay & Costa Rica \\
\hline
\end{tabular}

\section{EXHIBIT 4}

Individual Indicator coefficient discriminate function based on High, Medium or Low Debt

\begin{tabular}{|c|c|c|c|c|c|}
\hline $\begin{array}{c}\text { Classification } \\
\text { Matrix }\end{array}$ & $\begin{array}{c}\text { Current } \\
\text { Account in U.S. } \\
\text { Dollars } \\
\text { Correct \% }\end{array}$ & $\begin{array}{c}\text { Current } \\
\text { Account as } \\
\text { percent of GDP } \\
\text { Correct \% }\end{array}$ & $\begin{array}{c}\text { The GDP } \\
\text { measured in } \\
\text { Country's } \\
\text { currency } \\
\text { Correct \% }\end{array}$ & $\begin{array}{c}\text { Percent of } \\
\text { GDP Growth } \\
\text { Correct \% }\end{array}$ & $\begin{array}{c}\text { GDP in U.S. } \\
\text { Dollars } \\
\text { Correct \% }\end{array}$ \\
\hline $\begin{array}{c}\text { Group1: High } \\
\text { Debt Countries }\end{array}$ & $55.625^{*}$ & $55.00^{*}$ & $53.125^{*}$ & $55.00^{*}$ & 48.75 \\
\hline $\begin{array}{c}\text { Group 2: } \\
\text { Medium Level } \\
\text { Debt Countries }\end{array}$ & $71.25^{*}$ & $60.00^{*}$ & $76.25^{*}$ & 46.25 & 38.75 \\
\hline $\begin{array}{c}\text { Group 3: Low } \\
\text { Debt Countries }\end{array}$ & $90.00^{*}$ & 47.50 & $100.00^{*}$ & $63.125^{*}$ & $88.75^{*}$ \\
\hline $\begin{array}{c}\text { Overall \% } \\
\text { Correct }\end{array}$ & $72.29 *$ & $54.17 *$ & $76.46^{*}$ & $54.79^{*}$ & $58.75^{*}$ \\
\hline
\end{tabular}

* Indicates $\geq 50 \%$ correct 
Exhibit 4 shows that when the three groups were categorized based on their level of debt the high debt level countries are classified correctly in being affected by current account and domestic GDP but not GDP measured in dollars that could have been influenced due to other international factors that affect the dollar. The medium debt level had a stronger classification with respect to current account and domestic GDP than GDP growth or GDP in dollars. This would mean that policies promoting exports would probably be important to the economies of these countries with a medium level of debt. The lower debt countries were correctly categorized except with respect to current account as a percent of GDP indicating that the overall proportionality associated with this ratio is a lesser factor in the debt level. All of the macroeconomic factors seem to be significant, indicating that a change in the long term level of debt can have a major impact on the macroeconomic health of an economy.

\section{SUMMARY OF RESULTS AND FUTURE DIRECTIONS}

This study shows that the analysis of third world debt levels and debates on containing and managing them have made a full circle. Arguments about forgiveness and restructuring or limiting have always been discussed at world leader levels. This study supports the notion that Asian countries are more affected by debt factors influencing their economies versus countries in Latin America or Africa. However, there is stronger support for debt reduction in influencing economic activity worldwide. Debt levels influence the main macroeconomic factors that were detailed in this study.

Policy decisions to eliminate debt, reduce debt, or altogether forgive debt are supported in this study. Therefore, the debate on debt factors being curtailed has an additional proponent as a result of this study. However, the authors are aware that this analysis is not an exhaustive study and has limitations. Future studies could focus on individual countries and their management of debt or include a much larger sample of countries.

\section{REFERENCES:}

1. Clements B., Bhattacharya R., Nguyen, T.Q., Can Debt Relief Boost Growth in Poor Countries Economic Issues 34. IMF.

2. $\quad$ Country Monitor. October 16- 2006 Vol 14- Iss 38.

3. Hertz N., Why We Must Defuse the Debt Threat Contributions to Political Economy 24, pp. 123- 133.

4. WSJ, G-8 Warns Loans by Rising Nations May Swamp Poor

5. $\quad$ Ragsdale, C.T., Spreadsheet Modeling and Decision Analysis 3rd edition 2001

6. International Financial Statistics, $I M F$ various issues.

7. Moser, J.T., A Modest proposal: Securitizing multinational LDC debt Chicago Fed Letter: Sep 2000 Iss 157 pp.1-3

8. World Economic Outlook Statistical information various issues. 